Article

\title{
Work/Family Conflict of More Importance than Psychosocial Working Conditions and Family Conditions for Mental Wellbeing
}

\author{
Mikael Nordenmark ${ }^{1, *}$, Niclas Almén ${ }^{2}\left[\right.$ and Stig Vinberg ${ }^{1}$ (1) \\ 1 Department of Health Sciences, Mid Sweden University, SE-831 25 Östersund, Sweden; stig.vinberg@miun.se \\ 2 Department of Psychology and Social Work, Mid Sweden University, SE-831 25 Östersund, Sweden; \\ niclas.almen@miun.se \\ * Correspondence: mikael.nordenmark@miun.se
}

Received: 17 June 2020; Accepted: 10 September 2020; Published: 14 September 2020

check for updates

\begin{abstract}
Studies have indicated the importance of family life and psychosocial working conditions for mental wellbeing. More recently, studies have highlighted that a good balance between work and family is crucial for good mental wellbeing. However, few studies compare the relative importance of these factors for mental wellbeing. The main aim of this study was to analyse the relative importance of psychosocial working conditions, family conditions and work/family conflict for mental wellbeing. The analyses are based on a Swedish data set, including questions regarding working life, family life and mental wellbeing. A total of 12,461 married/cohabiting individuals employed in Swedish organisations were included in the study. Results show that psychosocial working conditions, family conditions and work/family conflict all were related to mental wellbeing. In the final regression model, the strongest correlation was found between mental wellbeing and the variables work/family conflict, satisfaction with private life and partner relationship, with work/family conflict appearing to be of greatest importance. These findings highlight the necessity of including measurements of work/family conflict when studying the importance of work and family conditions for individual mental wellbeing. For workplace health promotion and improvement, it may be beneficial to consider not only psychosocial working conditions, but also family conditions, and particularly work/life conflict.
\end{abstract}

Keywords: family conditions; mental wellbeing; psychosocial working conditions; work/family conflict

\section{Introduction}

Mental wellbeing is recognised as an important health indicator in research and policy debates [1], since it reflects a person's overall evaluation of their quality of life, happiness and satisfaction [2]. In addition, mental wellbeing is an important determinant of productivity at an individual, enterprise and societal level [3-5]. Psychosocial working conditions and family conditions are two life domains that have an impact on mental wellbeing. The balance between work and family is also of great importance [6].

Many studies have shown that good psychosocial working conditions are essential for psychological health and mental wellbeing [7]. However, European data indicates that work intensity and emotional demands have increased in working life since 2010 [8]. Data shows that around 25 percent of European workers experience work-related stress most of the time, and report that stress has a negative effect on their mental wellbeing [9]. In Sweden, around 65 percent of employees reported that a heavy workload was the main cause of work-related ill-health and reduced mental 
wellbeing [10,11]. In addition, since 2014, the most common cause of long-term sick-leave in Sweden is reduced mental wellbeing [12]. This is a worrying development, and it appears that increased research and practical measures concerning workplace health promotion have not been sufficiently effective in reducing work-related stress and increasing employee mental wellbeing [13]. Therefore, there is also a need to examine the conditions outside of individuals' work and their relative importance for employee mental wellbeing.

Studies have indicated that intimate relationships and good living conditions in one's private life are important for good wellbeing [14]. In recent years, studies have also highlighted the fact that a good balance between work and family is crucial for good mental wellbeing [6,15]. However, to our knowledge, no studies have tried to compare the relative importance of psychosocial working conditions, family conditions and work/family conflict for mental wellbeing, which is, therefore, the aim of this article.

\subsection{Psychosocial Working Conditions and Mental Wellbeing}

There are several suggested definitions of psychosocial working conditions. In this study, we refer to this concept in terms of the balance between work demands and resources available at work [16,17]. This balanced approach has been widely used for studies of relations between job characteristics and wellbeing [17-19]. Extensive research has shown that factors related to work content, work characteristics, work organisation and social relations are important for individual mental wellbeing [16,20-22].

Important work-stress-related factors include demands such as job strain and job insecurity, and resources such as job control and social support [11,23]. High work demands, a low level of job control and poor social support [16] are associated with different ill-health outcomes, such as mental ill-health and sick-leave [21,24,25]. In addition, high demands in combination with a high level of control lead to increased wellbeing, learning, motivation and skills development [16]. Different work stress models commonly hold that high work demands do not necessarily influence mental wellbeing outcomes negatively if they are combined with sufficient resources and rewards [17,26,27]. According to Siegrist's effort-reward imbalance model, a high level of effort spent combined with low reward can lead to strong negative emotions and stress reactions $[17,28]$. Insecure employment and worry about employment are considered determinants for poor mental wellbeing, although the mechanisms for how these issues harm employee wellbeing are unclear [29]. Nonetheless, perceived job insecurity has been linked to decreased mental wellbeing [30,31]. The risk of losing one's job may be as stressful as an actual job loss, because the uncertainty of the situation makes it difficult to take control and react appropriately [32].

Several studies show relationships between leadership behaviours and mental wellbeing; in particular, relation-oriented behaviours have been found to be associated with different wellbeing outcomes [33-37]. Some researchers state that psychosocial working conditions such as balanced work demands and a high level of control can be seen as mediating factors between leadership behaviours and employee mental wellbeing $[37,38]$.

In terms of Swedish working life, women in public sector workplaces have the highest level of sick-leave, and the negative development in psychosocial working conditions has been most pronounced in this sector $[11,39,40]$. Looking at trends over time, work demands have increased and decision-making authority and social support have decreased in the female-dominated sectors of education, health and social care in Sweden [20].

\subsection{Family Conditions and Mental Wellbeing}

Family relationships constitute perhaps an even more central domain than work in people's lives. Family can mean different things to different people. For some people, parents and grandparents can be part of the family, and for other people, a family includes a partner and/or children. Regardless of the kind of family one refers to, family is a central and important domain in most people's lives all 
around the world [41,42]. For example, studies have shown that people who have a partner generally have a higher level of life satisfaction and mental wellbeing than people living alone [43,44].

Family often offer love and close, intimate relationships, which have been shown to be of major importance for people's levels of life satisfaction and mental wellbeing $[14,45,46]$. However, most studies show that having children living at home has a negative or zero effect on mental wellbeing $[47,48]$. One explanation for these results is the negative impact on the household finances that often accompanies having children [49].

As can be expected, the quality of family relationships is critical; people who are satisfied with their partner relationship and family life have a higher level of mental wellbeing than those who have a more negative experience of their family situation [50,51]. Notably, people living in unhappy marriages seem to report a lower level of mental wellbeing than people living alone [52]. This highlights the importance of the level of satisfaction in one's partner relationship and family life for the level of one's mental wellbeing.

\subsection{Work/Family Conflict and Mental Wellbeing}

Kalliath and Brough [52] conclude that, if an individual perceives that work and non-work activities are compatible and promote growth in accordance with the individual's current life priorities, then there is a state of balance. However, if there is an imbalance between work and non-work activities there is a high risk of the individual experiencing work/life conflict [53].

An increasing number of individuals, both men and women, struggle with the challenges of fulfilling family responsibilities while simultaneously being employed [54]. Due to this, many women and men face what is called work/family imbalance or conflict, which means that the demands of one's work and family come into conflict with one another. There has therefore been increasing interest among researchers in studying work/family conflict in recent decades. Studies have analysed both the factors that contribute to an experience of work/family conflict and what the level of experienced work/family conflict means for mental wellbeing in individuals.

Studies that have investigated factors that contribute to an experience of work/family conflict have found that both structural and individual factors are important for determining the level of work/family conflict. At a structural level, family policy and gender norms have been shown to be important factors; most studies have shown that individuals living in countries with low family-policy spending and egalitarian gender norms are more likely to experience a high level of work/family conflict [53]. At an individual level, factors such as experiencing high demands on time, high work demands, job stress, low social support, parental demands and caring for children are factors that increase the risk of experiencing work/family conflict [53,55-58]. In terms of gender, the majority of studies have found that women experience a higher work/family conflict than men [6,59], but some studies indicate a higher work/family conflict in men [57].

Finally, and most importantly for the aim of this study, research has shown that work/family conflict is related to different mental wellbeing outcomes. Studies have shown that a lower level of work/family conflict fosters not only job satisfaction and job performance but also life and family satisfaction. Work/family balance also reduces stress-related outcomes such as psychological distress and emotional exhaustion [60]. If a person experiences a high level of work/family conflict, there is a greater risk of low mental wellbeing than if a person has a more balanced situation [6,15,53,54,61-64]. Some studies even indicate that perceived work/family conflict is more important for mental wellbeing than the actual time spent in paid and unpaid work [54].

\section{Aim and Research Questions}

In summary, a relatively large number of studies have shown associations between good psychosocial conditions and high mental wellbeing. Additionally, studies indicate the importance of intimate relationships, good living conditions in individuals' lives and a good work/family balance for a high level of mental wellbeing. However, few studies have compared the relative 
importance of psychosocial working conditions, family conditions and work/family conflict in relation to mental wellbeing.

The main aim of this study is to analyse the relative importance of psychosocial working conditions, family conditions and work/family conflict for mental wellbeing. This has been done by analysing the following research questions:

- How are psychosocial working conditions, family conditions and work/family conflict related to mental wellbeing?

- Which of psychosocial working conditions, family conditions and work/family conflict is most important for mental wellbeing?

\section{Materials \& Methods}

\subsection{Data and Subjects}

The data used in this study comes from something referred to as the Stress Profile (SP). The SP data has been collected during the course of Swedish real-life practical situations to obtain broad information on stress-related health variables. Questionnaires were distributed by occupational health professionals and human resource experts to individuals working in a variety of private and public organisations in different Swedish regions. The SP is a psychosocial tool derived from different areas of stress research, and it consists of 194 questions for measuring stress outside of work and at work at an individual, group and organisational level [65]. The SP includes 16 main fields (e.g., family conditions, sense of coherence, problem-solving and emotional stress reactions), which each belong to one of the following four areas: external causes of stress, internal causes of stress, coping with stress and stress reactions. In addition to these 194 questions measuring stress-related variables, the tool includes 20 background questions and ten criteria questions (primarily used for internal validations). The SP has been tested and standardised on more than 4000 subjects in Sweden [65]. Factorial validity tests have been conducted, and the reliability of the main fields of SP that emerged was tested using the test-retest, Cronbach's alpha, Spearman-Brown split-halves and maximum likelihood. The reliability coefficients have been defined as between 0.73 and 0.95 . The SP has been used and validated as a measurement tool in several studies [66-71].

Subjects were selected from the SP research database between 2006 and 2018 ( $\mathrm{n}=$ 17,422). Respondents included in the present study were persons who reported that they were married/cohabiting and employed in public or private organisations, which left 12,461 participants for the analyses. Of all the subjects included, $61.5 \%$ were women $(n=7663)$ and $38.5 \%$ were men $(n=$ 4795), $98.6 \%(n=12,273)$ reported that they were of Nordic nationality and $1.4 \%(n=172)$ reported a non-Nordic nationality and $61.5 \%(\mathrm{n}=7657)$ had at least one child in the household. With regard to education, $60.2 \%(n=7500)$ had a university degree. Ninety-seven percent $(n=11,843)$ were employed, and 3.0\% $(n=369)$ were self-employed. Of the respondents, $57.1 \%(n=7096)$ worked approximately $40 \mathrm{~h}$ per week (which is generally full time in Sweden), while 17.1\% $(\mathrm{n}=2129)$ worked less than $40 \mathrm{~h}$ and $25.8 \%(\mathrm{n}=3208)$ worked more than $40 \mathrm{~h}$.

\subsection{Dependent Variable}

Mental wellbeing is a broad concept that has been measured in various ways in earlier studies. One common way is to create indexes of variables related to worry, ability to deal with problems, sleeping problems, anxiety, strain, belief in the future etc., and an example of a commonly used measurement/index in earlier studies is the General Health Questionnaire (GHQ) [72]. In the present study, an index called mental wellbeing was created, which we used as a dependent variable. The index consists of 12 items including anxiety, restlessness, depression, fatigue and helplessness, as well as cognitive functioning, such as difficulties in making decisions, concentrating, remembering and thinking clearly (e.g., how often during the last month have you experienced fatigue? How often during the last month have you experienced difficulties thinking clearly?). The participants were asked 
how often they experienced these emotional and cognitive reactions. Cronbach's alpha in the sample by Setterlind and Larsson [65] was 0.84 for emotional reactions and 0.90 for cognitive reactions. A factor analysis (principal component analysis using Varimax; analysis not shown) of all questions in these two fields indicated that all of the questions can be seen as representing a single dimension that, in our study, is called mental wellbeing (factor loadings of between 0.656 and 0.849 and Cronbach's alpha of 0.93).

\subsection{Independent Variables}

In the present study, ten independent variables were used to represent the three areas: psychosocial working conditions, family conditions and work/family conflict. Work/family conflict consisted of a subfield with the same name (three items about time for family and friends, conflict and demands between work and private life; e.g., I experience an imbalance between work and private life; factor loadings of between 0.859 and 0.881 and Cronbach's alpha of 0.83 ). Table 1 presents factor loadings from two separate factor analyses of variables measuring psychosocial working conditions and family conditions. Based on the factor analyses of psychosocial working conditions, the following six subfields of the SP were included: control at work (three items about the ability to influence and plan work; e.g., I have good opportunities to influence planning of work; Cronbach's alpha of 0.82), demands at work (three items about work and contradicting demands; e.g., the demands are too high at work; Cronbach's alpha of 0.75), leadership trust (two items about trust in, and ability among, leaders; e.g., I trust the leaders; Cronbach's alpha of 0.83 ), worry about employment (two items regarding worrying about losing one's job; e.g., I worry about losing my job within a year; Cronbach's alpha of 0.84 ), social support (two items about social support and team spirit; e.g., I experience that we support each other at my work; Cronbach's alpha of 0.83 ) and wage and reward (two items about reward related to salary; e.g., good work gets rewarded; Cronbach's alpha of 0.60). The factor analysis of variables measuring family conditions resulted in the following subfields: partner relationship (three items about love and relationship to one's partner; e.g., I get enough love and support from my partner; Cronbach's alpha of 0.87), economic situation (three items about status of household finances; e.g., I experience problems with household finances; Cronbach's alpha of 0.90) and satisfaction with private life (I am satisfied with my private life).

Table 1. Factor analysis of variables measuring psychosocial working conditions and family conditions (factor loadings).

\begin{tabular}{|c|c|c|c|c|c|c|}
\hline Variables & Factor 1 & Factor 2 & Factor 3 & Factor 4 & Factor 5 & Factor 6 \\
\hline \multicolumn{7}{|l|}{ Psychosocial working conditions } \\
\hline Influence on planning of work & 0.827 & & & & & \\
\hline Influence on implementation of work & 0.841 & & & & & \\
\hline Being part of the planning of work & 0.735 & & & & & \\
\hline Demands too high at work & & 0.800 & & & & \\
\hline Contradicting work demands & & 0.748 & & & & \\
\hline Work demands mentally strenuous & & 0.816 & & & & \\
\hline Feel that leaders develop work & & & 0.849 & & & \\
\hline Trust in leaders & & & 0.833 & & & \\
\hline Worry about organisational change & & & & 0.918 & & \\
\hline Worry about employment status & & & & 0.920 & & \\
\hline Feedback at work & & & & & 0.897 & \\
\hline Appreciation at work & & & & & 0.779 & \\
\hline Good work gets rewarded & & & & & & 0.737 \\
\hline Pleased with salary & & & & & & 0.876 \\
\hline \multicolumn{7}{|l|}{ Family conditions } \\
\hline Relationship to partner & 0.880 & & & & & \\
\hline Similar opinions as partner & 0.879 & & & & & \\
\hline Love from partner & 0.892 & & & & & \\
\hline
\end{tabular}


Table 1. Cont.

\begin{tabular}{|c|c|c|c|c|c|c|}
\hline Variables & Factor 1 & Factor 2 & Factor 3 & Factor 4 & Factor 5 & Factor 6 \\
\hline Problems with household finances & & 0.913 & & & & \\
\hline Worsening private finances & & 0.922 & & & & \\
\hline Worsening living conditions & & 0.862 & & & & \\
\hline Satisfaction with private life & & & 0.869 & & & \\
\hline
\end{tabular}

Extraction method: principal component analysis. Rotation method: Varimax with Kaiser normalisation.

For all questions used in the present study, the Likert-type scale ranged from 1 (strongly agree/strongly/very often) to 5 (strongly disagree/not at all/never). Some variables were recoded so that all variables varied from 1 (=good conditions) to 5 (=bad conditions).

The following demographic data were used as control variables: gender $(1=$ woman, $0=\operatorname{man})$, age, level of education, children $(1=$ children living at home, $0=$ no children or no children living at home) and nationality $(1=$ Nordic, $0=$ non-Nordic $)$.

\subsection{Statistical Analyses}

Descriptive statistics for the socioeconomic data were calculated using percentages, and mean and medium values were calculated for the dependent and independent variables. Factor analyses (principal component analysis) were performed for variables measuring psychosocial working conditions and family conditions and Cronbach's alpha values were computed in order to estimate the internal reliability (i.e., internal consistency) for the variables used. Ordinary least squares (OLS) regressions were performed to analyse relations between independent variables and the dependent variable. The first three models analysed psychosocial working conditions, family conditions and work/family conditions by mental wellbeing. The final model consists of a multivariate analysis, including all independent variables and demographic variables. All analyses were also performed for women and men separately (tables not shown) and notable gender differences are commented on in the text in relation to each table.

\section{Results}

Table 2 shows the Cronbach's alpha values, means, medians and $\mathrm{N}$ for all the main variables measuring psychosocial working conditions, family conditions, work/family conflict and mental wellbeing. All values vary between 1 and 5, and the higher the value, the worse the conditions. The Cronbach's alpha values indicate that all indexes have a value higher than 0.69 , apart from the index of wage and reward, which has a Cronbach's alpha of 0.60 . The mean values show that the conditions that are perceived as most problematic for the respondents are, in order, wage and reward (mean 3.3), work/family conflict (mean 3.0) and demands at work (mean 2.9). The conditions that respondents are most satisfied with are, in order, partner relationship (mean 1.7), financial situation (mean 1.7), worry about employment (mean 1.9) and satisfaction with private life (mean 1.9). Regarding gender, the mean values for wage and reward and work/family conflict are higher among women than among men, indicating that women experiences these conditions as more problematic. 
Table 2. Mean values of variables measuring psychosocial working conditions, family conditions, work/family conflict and mental wellbeing $(1=\operatorname{good}$ conditions $-5=$ bad conditions $)$.

\begin{tabular}{lcccc}
\hline \multicolumn{1}{c}{ Variables } & Cronbach's Alpha & Mean & Median & N \\
\hline Psychosocial working conditions & & & & \\
Demands at work & 0.75 & 2.9 & 3.0 & 12,447 \\
Control at work & 0.82 & 2.2 & 2.0 & 12,449 \\
Social support & 0.83 & 2.4 & 2.0 & 12,439 \\
Leadership trust & 0.83 & 2.7 & 2.5 & 12,159 \\
Worry about employment & 0.84 & 1.9 & 1.5 & 12,440 \\
Wage and reward & 0.60 & 3.3 & 3.5 & 12,439 \\
\hline Family conditions & & & & \\
Partner relationship & 0.87 & 1.7 & 1.3 & 12,428 \\
Satisfaction with private life & - & 1.9 & 2.0 & 12,408 \\
Financial situation & 0.90 & 1.7 & 2.0 & 12,423 \\
\hline Work/family conflict & 0.83 & 3.0 & 3.0 & 12,452 \\
\hline Mental wellbeing & 0.93 & 2.7 & 2.6 & 12,446 \\
\hline
\end{tabular}

Table 3 illustrates the extent to which the main variables correlate with one another. First, one can conclude that all the main variables significantly correlate with one another. However, no correlation between the independent variables is higher than 0.61 , which indicates that the risk of multicollinearity between the independent variables is relatively low (to avoid multicollinearity the recommended upper limit is 0.8 ). At this stage of the analysis, one can see that work/family conflict strongly correlates with mental wellbeing (0.66). Other correlations that are stronger than 0.45 include the correlation between the variables partner relationship and satisfaction with private life, demands at work and work/family conflict, demands at work and mental wellbeing, control at work and leadership trust, and social support and leadership trust. The following correlations are significantly stronger among men: control at work and satisfaction with private life, wage and reward and satisfaction with private life, demands at work and worry about employment, worry about employment and work/family conflict, worry about employment and mental wellbeing, wage and reward and satisfaction with private life.

Table 3. Correlations between main variables (Pearson).

\begin{tabular}{|c|c|c|c|c|c|c|c|c|c|c|}
\hline & Demands & Control & $\begin{array}{l}\text { Social } \\
\text { Supp }\end{array}$ & Leadership & Worry & Wage & Partner & Satisfied & Finances & Conflict \\
\hline Demands & - & & & & & & & & & \\
\hline Control & 0.35 & - & & & & & & & & \\
\hline Social sup & 0.25 & 0.38 & - & & & & & & & \\
\hline Leader & 0.33 & 0.46 & 0.46 & - & & & & & & \\
\hline Worry & 0.18 & 0.24 & 0.16 & 0.20 & - & & & & & \\
\hline Wage & 0.19 & 0.31 & 0.22 & 0.38 & 0.10 & - & & & & \\
\hline Partner & 0.09 & 0.07 & 0.10 & 0.10 & 0.07 & 0.03 & - & & & \\
\hline Satisfied & 0.15 & 0.14 & 0.14 & 0.13 & 0.13 & 0.06 & 0.61 & - & & \\
\hline Finances & 0.07 & 0.17 & 0.12 & 0.11 & 0.21 & 0.19 & 0.22 & 0.32 & - & \\
\hline Conflict & 0.58 & 0.27 & 0.22 & 0.23 & 0.17 & 0.12 & 0.21 & 0.34 & 0.16 & - \\
\hline Wellbeing & 0.50 & 0.33 & 0.26 & 0.25 & 0.25 & 0.16 & 0.21 & 0.38 & 0.24 & 0.66 \\
\hline
\end{tabular}

All correlations are significant at the 0.01 level (2-tailed). Pearson $>0.40$ in bold.

OLS regressions were conducted to analyse how the independent variables related to mental wellbeing when controlling for one another. Model 1 in Table 4 illustrates the coefficients for the variables measuring psychosocial working conditions when controlled for one another. Model 2 presents the coefficients for the variables measuring family conditions when controlled for one another. Model 3 presents the coefficient for work/family conflict, and finally, Model 4 is a multivariate analysis of all main independent variables controlled for the demographic variables gender, age, education, children and nationality. 
Table 4. Ordinary least squares (OLS) regression. Psychosocial working conditions, family conditions, work/family conflict and background characteristics by mental wellbeing (unstandardised B-coefficients).

\begin{tabular}{|c|c|c|c|c|c|}
\hline Independent Variables & Model 1 & Model 2 & Model 3 & Model 4 & VIF Model 4 \\
\hline Constant & $0.887 * * *$ & 1.855 & 1.067 & 0.436 & \\
\hline Demands at work & $0.364^{* * *}$ & & & $0.140^{* * *}$ & 1.703 \\
\hline Control at work & $0.129^{* * *}$ & & & $0.061^{* * *}$ & 1.509 \\
\hline Social support & $0.094^{* * *}$ & & & $0.047^{* * *}$ & 1.343 \\
\hline Leadership trust & $-0.017 *$ & & & 0.007 & 1.609 \\
\hline Worry about employment & $0.109 * * *$ & & & $0.057^{* * *}$ & 1.130 \\
\hline Wage and reward & 0.014 & & & -0.009 & 1.252 \\
\hline Partner relationship & & $-0.037 * *$ & & $-0.021 *$ & 1.626 \\
\hline Satisfaction with private life & & $0.340^{* * *}$ & & $0.156^{* * *}$ & 1.832 \\
\hline Financial situation & & $0.134^{* * *}$ & & $0.067^{* * *}$ & 1.217 \\
\hline Work/family conflict & & & $0.527^{* * *}$ & $0.368^{* * *}$ & 1.758 \\
\hline Gender & & & & $0.298^{* * *}$ & 1.052 \\
\hline Age & & & & $-0.013 *$ & 1.110 \\
\hline Education & & & & $-0.083^{* * *}$ & 1.101 \\
\hline Children & & & & $-0.062^{* * *}$ & 1.081 \\
\hline Nationality & & & & $-0.122 *$ & 1.006 \\
\hline $\mathrm{R}^{2}$ & 0.30 & 0.16 & 0.44 & 0.55 & \\
\hline
\end{tabular}

Model 1 in Table 4 shows that all variables measuring psychosocial working conditions, with the exception of wage and reward, are significantly related to mental wellbeing. Further, the coefficient for leadership trust relates significantly negatively to mental wellbeing in a multivariate analysis. All other variables measuring psychosocial working conditions are positively related to mental wellbeing, the worse the degree to which the conditions are experienced, the lower the level of mental wellbeing. The strongest relationship is between demands at work and mental wellbeing, indicating the importance of this condition to the level of mental wellbeing. Model 2 shows that the variables measuring family conditions are highly relevant when studying mental wellbeing. Both satisfaction with private life and financial situation are strongly related to mental wellbeing; the lower the satisfaction and the worse the financial situation, the poorer the mental wellbeing. Surprisingly, the coefficient for the variable partner relationship becomes negative when controlling for the other variables measuring family conditions, which may be explained by the fact that this variable strongly correlates to satisfaction with private life.

Model 3 illustrates that work/family conflict is strongly related to mental wellbeing, in that a high level of conflict substantially increases the risk of poor mental wellbeing.

The work/family conflict index itself explains $44 \%$ of the variance in the dependent variable. Although this dimension is represented by only one index/variable, the R-squared value is higher in Model 3 than in Models 1 and 2.

All of the main variables are included in Model 4, plus the variables measuring some demographic conditions. In this model, all variables are significantly related to mental wellbeing. However, the strongest relationship is found between work/family conflict and mental wellbeing. The second strongest relationship among the main variables is the relationship between satisfaction with private life and mental wellbeing. The demographic variables are related to health in the following ways. Women have a higher risk of experiencing poor mental wellbeing. The higher the age, the better the mental wellbeing. People with a university education and people that have children living at home have a lower risk of experiencing low mental wellbeing. People with a Nordic nationality have a significantly higher level of mental wellbeing than people with a non-Nordic nationality. The R-squared value for 
Model 4 is 0.55 . Separate analyses of women and men show that all independent variables in Model 4 are related to mental wellbeing in a similar way among both women and men.

The last column in Table 4 presents the VIF values for all variables in Model 4 . The values vary between 1.006 and 1.758 , indicating that the risk for multicollinearity is relatively low (to avoid multicollinearity the recommended upper limit is VIF $>5$ [73]).

\section{Discussion}

To our knowledge, studies have not analysed which of psychosocial working conditions, family conditions and work/family conflict has the greatest impact on mental wellbeing. Therefore, the main aim of this study was to analyse the relative importance of these conditions for mental wellbeing. The results showed that psychosocial working conditions, family conditions and work/family conflict are all related to mental wellbeing, but work/family conflict seems more strongly related to mental wellbeing than both work and family conditions. These findings highlight the need to include measurements of work/family conflict when studying the importance of work and family conditions for mental wellbeing.

The most prominent results in this study are the strong associations between work/family conflict and family conditions, and the dependent variable mental wellbeing. This is in line with other research $[53,54,61]$ and emphasises that there are good reasons to consider these areas when trying to create healthy work organisations and strengthen employee mental wellbeing. Today's working life is largely characterised by work without boundaries [74,75], leading to flexible working conditions but also to unclear boundaries that can influence work/life balance and family life negatively (ibid.). In Sweden, and especially in female-dominated workplaces (approximately 62\% of the participants in our study were women), psychosocial working conditions have become more psychosocially demanding $[39,76]$, which could negatively influence work/life balance and family conditions. A contribution to earlier research that point out the importance of work/family conflict for wellbeing is that the results from this study support that work/family conflict seems to be of even more importance for mental wellbeing than both psychosocial working conditions and family conditions per se.

The results also indicate that several factors related to psychosocial working conditions, family conditions and work/family conflict are associated with mental wellbeing. Interestingly, the OLS regression analyses showed a relatively high explained variance in the final model $\left(\mathrm{R}^{2}=0.55\right)$. This is in line with research about healthy work organisations that points to the importance of a holistic view that takes into account many different factors, both organisational and individual, when creating improvements in such organisations $[22,77,78]$. However, it is worth noting that measurements of family conditions and work/life conflict are rarely included in these studies. The literature and models about healthy work organisations mainly focus on psychosocial and physical working environment factors, leadership and learning issues [22]. Our study contributes to these models by also considering factors related to work/family conflict and family conditions.

The final regression model results showing that demands at work, control at work and social support are related to mental wellbeing are supported by studies about work stress models [16,19]. Surprisingly, other important work stress factors, such as wage and reward [17,28], do not have a significant connection to mental wellbeing. Worry about employment, an indicator of job insecurity, is related to mental wellbeing, which is in accordance with other research $[23,29,30]$. All the variables related to family conditions are, as assumed, strongly related to mental wellbeing and these results support earlier research about the importance of the quality of close relationships for wellbeing [14,45, $46,61]$.

Extensive research indicates that leadership styles, especially relation-oriented styles, are related to a number of employee mental wellbeing outcomes and organisational outcomes such as quality and efficiency outcomes [33-35,37,38]. The fact that leadership trust does not contribute significantly to mental wellbeing in the final regression model may partly be explained by the fact that leadership trust measures the extent to which employees value their leader, not how they rate leadership styles. 
Another explanation could be that leadership behaviours influence mediating psychosocial working condition factors that, in turn, influence mental wellbeing [37].

The present study was not designed to investigate how the strong relationship between work/family conflict and wellbeing can best be explained. Therefore, our results can only contribute to hypothetical explanations. Several researchers explain stress-related ill health and poor mental wellbeing in terms of a lack of recovery after periods of stress and strain [79-81], and adding stress recovery to a model consisting of work characteristics has been shown to considerably impact mental wellbeing outcomes [80]. Stress recovery has been conceptualised as a process of psychophysiological deactivation after effort expenditure [82], and recovery processes are usually assumed to occur post-work. In contrast, Almén [83] assumes that behaviours that facilitate recovery should ideally be applied both at work and outside of work. In a study by Lisspers et al. [71] increased levels of "recovery behaviour" at work (such as taking a coffee break or performing a completely different type of task for a while) prospectively predicted improved levels of mental wellbeing. Experiencing difficulties in living up to perceived demands both at home and at work, which, in our study, was used as an indicator of work/family conflict, probably contributes to a difficulty in applying recovery behaviours both at work and at home (such as relaxing, reading a book or exercising).

Despite uncertainty about the reasons for work/life conflict being the strongest of the independent variables related to mental wellbeing, the results highlight the need to include measurements of work/family conflict when studying the importance of work and family conditions for mental wellbeing.

\subsection{Strengths and Limitations}

A methodological weakness of this study is that the individuals and workplaces included are not part of a randomly selected sample and cover only a Swedish context. However, they represent a variety of private and public organisations and occupational professions in different regions across Sweden for the time period from 2006 to 2018. Since the participants were also employed and married/cohabiting, the results should be interpreted based on this specific group; individuals who are not employed and/or who live alone may have different scores for the independent and dependent variables studied. Another weakness is that some indicators and indexes consist of only one or two questions which increases the risk that these dimensions are not fully measured. As the data were cross-sectional, we cannot draw conclusions on causal relationships. One strength of the study is the relatively extensive data set and the use of validated measures. Another strength is that the variables included in the indexes are strongly correlated to one another, and both the Cronbach's alpha values and the factor analysis supported the indexes used.

\subsection{Conclusions and Implications}

This study found that psychosocial working conditions, family conditions and work/family conflict were significantly related to mental wellbeing in married/cohabiting employees. Work/family conflict in particular seems to be of importance for mental wellbeing, which is indicated by the high Pearson's values and coefficients for the relationship between the variables work/family conflict and mental wellbeing. These results highlight the value of taking into account a variety of factors when trying to create health-promoting workplaces and improve employee mental wellbeing. Another conclusion is that, over and above psychosocial working conditions, it may also be beneficial to consider, family conditions and work/life conflict in particular, when working with such improvements.

Importantly, managers and co-workers together should analyse the status of psychosocial working conditions, work/family conflict and family conditions at their workplaces and, based on such analyses, implement holistic workplace health promotion measures which incorporate all three areas. Managers can seek to explore issues related not only to psychosocial working conditions, but also to family conditions and work/family conflict in dialogues with employees and when performing workplace surveys. Other important measures include increasing the employee's possibilities to steer their work situation through organisational and flexible working hour measures. At a societal and governmental 
level, it is valuable to include aspects related to family conditions and work/family conflict when developing and implementing working condition policies and regulations. It is also important to develop and implement family policies that take into account how psychosocial working conditions interact with factors outside of work for both men and women in working life. Another implication is that public health policies should include psychosocial working conditions and working hour regulations, together with measures for good family conditions, in order to achieve a work/life balance for employees.

\subsection{Further Research}

The results of the present study warrant further research. It is important to conduct studies to confirm the results of the present study using samples from other populations and perhaps other measurements to validate and generalise the findings. Furthermore, it is important to use longitudinal designs to increase the possibility of drawing conclusions about causal relationships between the independent variables and the dependent variable. It would also be interesting to analyse certain combinations of predictors to explore moderating and buffering effects in relation to mental wellbeing. It could also be valuable to conduct qualitative studies in different sectors to create more knowledge about the relative importance of psychosocial working conditions, family conditions and work/life conflict for mental wellbeing. Finally, we would like to encourage research colleagues to conduct intervention studies in which the relative importance of psychosocial working conditions, family conditions and work/life conflict is tested. For example, one could do a three-arm randomised controlled intervention study aimed at comparing interventions with the following purposes: (1) improvement in psychosocial working conditions; (2) improvements in family conditions; and (3) improvements in work/life balance.

Author Contributions: Conceptualization, M.N., N.A. and S.V.; writing-original draft preparation, M.N., N.A. and S.V.; methodology M.N. and N.A., design and statistical analyses, M.N.; writing-review \& editing, M.N., N.A. and S.V. All authors have read and agreed to the published version of the manuscript.

Funding: This research received no external funding.

Conflicts of Interest: The authors declare no conflict of interest.

\section{References}

1. Graham, C.; Laffan, K.; Pinto, S. Well-being in metrics and policy. Science 2018, 362, 287-288. [CrossRef]

2. Topp, C.W.; Østergaard, S.D.; Søndergaard, S.; Bech, P. The WHO-5 Well-Being Index: A systematic review of the literature. Psychother. Psychosom. 2015, 84, 167-176. [CrossRef] [PubMed]

3. Hassard, J.; Teoh, K.R.H.; Visockaite, G.; Dewe, P.; Cox, T. The cost of work-related stress to society: A systematic review. J. Occup. Health Psychol. 2018, 23, 1-17. [CrossRef] [PubMed]

4. OECD/EU. Health at a Glance: Europe 2018: State of Health in the EU Cycle; OECD Publishing: Paris, France, 2018. [CrossRef]

5. Schulte, P.; Vainio, H. Well-being at work: Overview and perspective. Scand. J. Work Environ. Health 2010, 36, 422-429. [CrossRef] [PubMed]

6. Lunau, T.; Bambra, C.; Eikemo, T.A.; van der Wel, K.A.; Dragano, N. A balancing act? Work-life balance, health and mental wellbeing in European welfare states. Eur. J. Public Health 2014, 24, 422-427. [CrossRef] [PubMed]

7. Bliese, P.D.; Edwards, J.R.; Sonnentag, S. Stress and well-being at work. A century of empirical trends reflecting theoretical and societal influences. J. Appl. Psychol. 2017, 102, 389-402. [CrossRef]

8. Eurofound. Working Conditions and Workers' Health; Publications Office of the European Union: Luxembourg, 2019.

9. Eurofond \& EU-OSHA. Psychosocial Risks in Europe: Prevalence and Strategies for Prevention; Publications Office of the European Union: Luxembourg, 2014.

10. Arbetsmiljöverket [The Swedish Work Environment]. Arbetsrelaterade Besvär [Work-Related Disorders]; The Swedish Work Environment: Stockholm, Sweden, 2018. 
11. Sverke, M.; Falkenberg, H.; Kecklund, G.; Magnusson Hanson, L.; Lindfors, P. Kvinnors och Mäns Arbetsvillkor-Betydelsen av Organisatoriska Faktorer och Psykosocial Arbetsmiljö för Arbets- och Hälsorelaterade Utfall [Womens and Mens Working Conditions-the Importance of Organizational Factors and Psychosocial Working Environment for Work- and Health-Related Outcomes]. Available online: https://www.av.se/globalassets/filer/publikationer/kunskapssammanstallningar/kvinnors-och-mansarbetsvillkor-kunskapssammanstallning-rap-2016-2.pdf (accessed on 1 April 2020).

12. Försäkringskassan [Swedish Social Insurance Agency]. Sjukfrånvarons Utveckling 2016 [The Development of Sickness Absence 2016]; Swedish Social Insurance Agency: Stockholm, Sweden, 2016.

13. Bhui, K.S.; Dinos, S.; Stansfeld, S.A.; White, P.D. A Synthesis of the Evidence for Managing Stress at Work: A Review of the Reviews Reporting on Anxiety, Depression, and Absenteeism. J. Environ. Public Health 2012. [CrossRef]

14. Ateca-Amestoy, V.; Aguilar, A.C.; Moro-Egido, A.I. Social Interactions and Life Satisfaction: Evidence from Latin America. J. Happiness Stud. 2014, 15, 527-554. [CrossRef]

15. Zheng, C.; Kashi, K.; Fan, D.; Molineux, J.; Ee, M.S. Impact of individual coping strategies and organisational work-life balance programmes on Australian employee mental wellbeing. Int. J. Hum. Resour. Manag. 2016, 27, 501-526. [CrossRef]

16. Karasek, R.; Theorell, T. Healthy Work: Job Stress, Productivity and the Reconstruction of Working Life; Basic Books: New York, NY, USA, 1990.

17. Siegrist, J. Adverse health effects of high-effort/low-reward conditions. J. Occup. Health Psychol. 1996, 1, 27-41. [CrossRef]

18. Cooper, C.L.; Dewe, P.J.; O'Driscoll, M.P. Organizational Stress: A Review and Critique of Theory, Research, and Applications; Sage: Thousand Oaks, CA, USA, 2001.

19. Theorell, T. Handbook of Socioeconomic Determinants of Occupational Health: From Macro-Level to Micro-Level Evidence; Springer: Basel, Switzerland, 2020.

20. Cerdas, S.; Härenstam, A.; Johansson, G.; Nyberg, A. Development of job demands, decision authority and social support in industries with different gender composition-Sweden, 1991-2013. BMC Public Health 2019, 19, 758. [CrossRef] [PubMed]

21. Theorell, T.; Hammarstrom, A.; Aronsson, G.; Bendz, L.T.; Grape, T.; Hogstedt, C.; Marteinsdottir, I.; Skoog, I.; Call, C. A systematic review including meta-analysis of work environment and depressive symptoms. BMC Public Health 2015, 15, 738. [CrossRef] [PubMed]

22. Lindberg, P.; Vingård, E. Indicators of healthy work environments-A systematic review. Work 2012, 41 (Suppl. 1), 3032-3038. [CrossRef]

23. Probst, T.M. Countering the Negative Effects of Job Insecurity Through Participative Decision Making: Lessons From the Demand-Control Model. J. Occup. Health Psychol. 2005, 10, 320-329. [CrossRef] [PubMed]

24. Aronsson, G.; Theorell, T.; Grape, T.; Hammarstrom, A.; Hogstedt, C.; Marteinsdottir, I.; Hall, C. A systematic review including meta-analysis of work environment and burnout symptoms. BMC Public Health 2017, 17, 264. [CrossRef] [PubMed]

25. Stansfeld, S.; Candy, B. Psychosocial work environment and mental health-A meta-analytic review. Scand. J. Work Environ. Health 2006, 32, 443-462. [CrossRef]

26. De Jonge, J.; Dormann, C. Stressors, Resources, and Strain at Work: A Longitudinal Test of the Triple-Match Principle. J. Appl. Psychol. 2006, 91, 1359-1374. [CrossRef]

27. Demerouti, E.; Bakker, A.; Nachreiner, F.; Schaufeli, W. The job demands-resources model of burnout. J. Appl. Psychol. 2001, 86, 499-512. [CrossRef]

28. Siegrist, J.; Wahrendorf, M.E. Work Stress and Health in a Globalized Economy: The Model of Effort-Reward Imbalance; Springer: Basel, Switzerland, 2016.

29. Jonsson, J.; Vives, A.; Benach, J.; Kjellberg, K.; Selander, J.; Johansson, G.; Bodin, T. Measuring precarious employment in Sweden: Translation, adaptation and psychometric properties of the Employment Precariousness Scale (EPRES). BMJ Open 2019, 9, e029577. [CrossRef]

30. Cheng, G.H.L.; Chan, D.K.S. Who sufers more from job insecurity? A meta-analytic review. Appl. Psychol. 2008, 57, 272-303. [CrossRef]

31. Jiang, L.; Lavaysse, L.M. Cognitive and afective job insecurity: A meta-analysis and a primary study. J. Manag. 2018, 44, 2307-2342. [CrossRef] 
32. De Witte, H.; Pienaar, J.; De Cuyper, N. Review of 30 years of longitudinal studies on the association between job insecurity and health and mental wellbeing: Is there causal evidence? Aust. Psychol. 2016, 51, 18-31. [CrossRef]

33. Kuoppala, J.; Lamminpaa, A.; Liira, J.; Vainio, H. Leadership, job mental wellbeing, and health effects-A systematic review and a meta-analysis. J. Occup. Environ. Med. 2008, 50, 904-915. [CrossRef]

34. Larsson, J.; Vinberg, S. Leadership behaviour in successful organisations: Universal or situation-dependent? Total Qual. Manag. 2010, 21, 317-334. [CrossRef]

35. Skakon, J.; Nielsen, K.; Borg, V.; Guzman, J. Are leaders' mental wellbeing, behaviours and style associated with the affective mental wellbeing of their employees? A systematic review of three decades of research. Work Stress 2010, 24, 107-139. [CrossRef]

36. Nyberg, A.; Bernin, P.; Theorell, T. The Impact of Leadership on the Health of Subordinates; (SALTSA, Report nr. 1); Arbetslivsinstitutet: Stockholm, Sweden, 2005; Available online: http://www.su.se/polopoly_fs/1.51750. 1321891474!/P2456_AN.pdf (accessed on 1 April 2020).

37. Nyberg, A.; Westerlund, H.; Magnusson Hanson, L.L.; Theorell, T. Managerial leadership is associated with self-reported sickness absence and sickness presenteeism among Swedish men and women. Scand. J. Public Health 2008, 36, 803-811. [CrossRef] [PubMed]

38. Harms, P.D.; Credé, M.; Tynan, M.; Leon, M.; Jeung, W. Leadership and stress: A meta-analytic review. Leadersh. Q. 2017, 28, 178-194. [CrossRef]

39. Berntson, E.; Wallin, L.; Härenstam, A. Typical situations for managers in the Swedish public sector: Cluster analysis of working conditions using the job demands-resources model. Int. Public Manag. J. 2012, 15, 100-130. [CrossRef]

40. Lidwall, U.; Marklund, S. What is Healthy Work for Women and Men?-A Case-Control Study of Genderand Sector-Specific Effects of Psycho-Social Working Conditions on Long-Term Sickness Absence. Work A J. Prev. Assess. Rehabil. 2006, 27, 153-163. Available online: http://search.ebscohost.com/login.aspx?direct= trueanddb $=c 8$ hand AN=106370527andsite=ehost-live (accessed on 1 April 2020).

41. Gaunt, D. Family Forms in Historic Europe; University Press: Cambridge, UK, 1983.

42. Nordenmark, M. The importance of job and family satisfaction for happiness among women and men in different gender regimes. Societies 2018, 8, 1. [CrossRef]

43. Ben-Zur, H. Loneliness, Optimism, and Mental wellbeing Among Married, Divorced, and Widowed Individuals. J. Psychol. 2012, 146, 23-36. [CrossRef] [PubMed]

44. Diener, E.; Ingelhart, R.; Tay, L. Theory and validity of life satisfaction scales. Soc. Indic. Res. 2013, 112, 497-527. [CrossRef]

45. Furnham, A.; Cheng, H. Lay theories of happiness. J. Happiness Stud. 2000, 1, 227-246. [CrossRef]

46. Layard, R. Happiness: Lessons from a New Science; Penguin: London, UK, 2006.

47. Angeles, L. Children and Life satisfactions. J. Happiness Stud. 2010, 11, 523-538. [CrossRef]

48. Stanca, L. Suffer the little children: Measuring the effects of parenthood on well-being worldwide. J. Econ. Behav. Organ. 2012, 81, 742-750. [CrossRef]

49. Nordenmark, M. Unemployment and family life: The relationship among employment status, household division of labour and mental wellbeing. In Walking a Tightrope: Meeting the Challenges of Work and Family; Harvey, C., Ed.; Ashgate: London, UK, 2000.

50. Rupert, P.A.; Stevanovic, P.; Tuminello Hartman, E.R.; Bryant, F.B.; Miller, A. Predicting work-family conflict and life satisfaction among professional psychologists. Prof. Psychol. Res. Pract. 2012, 43, 341-348. [CrossRef]

51. Chapman, B.; Guven, C. Revisiting the Relationship Between Marriage and Mental wellbeing: Does Marriage Quality Matter? J. Happiness Stud. 2016, 17, 533. [CrossRef]

52. Kalliath, T.; Brough, P. Work-life balance: A review of the balance construct. J. Manag. Organ. 2008, 14, 323-327. [CrossRef]

53. Strandh, M.; Nordenmark, M. The interference of paid work with household demands in different social policy contexts: Perceived work-household conflict in Sweden, the UK, the Netherlands, Hungary, and the Czech Republic. Br. J. Sociol. 2006, 57, 597-617. [CrossRef]

54. Hagqvist, E.; Gådin, K.G.; Nordenmark, M. Division of labor, perceived labor-related stress and mental wellbeing among European couples. Open J. Prev. Med. 2012, 2, 452-460. [CrossRef]

55. Byron, K. A meta-analytic review of work-family conflict and its antecedents. J. Vocat. Behav. 2005, 62, 169-198. [CrossRef] 
56. Chung, H. Work-family conflict across 28 European countries: A multilevel approach. In Work-Life Balance in Europe; Drobnic, S., Guillén, A.M., Eds.; Palgrave Macmillan: Hampshire, UK, 2011.

57. Fahlén, S. Does gender matter? Policies, norms and the gender gap in work-to-home and home-to-work conflict across Europe. Community Work Family 2014, 17, 371-391. [CrossRef]

58. Michel, J.S.; Kotrba, L.M.; Mitchelson, J.K.; Clark, M.A. Baltes BB: Antecedents of work-family conflict: A meta-analytic review. J. Organ. Behav. 2011, 32, 689-725. [CrossRef]

59. Gutek, B.; Searle, S.; Klepa, L. Rational versus gender role explanations for work-family conflict. J. Appl. Psychol. 1991, 76, 560-568. [CrossRef]

60. Sirgy, M.J.; Lee, D.J. Work-life balnce: An integrative review. Appl. Res. Qual. Life 2018, 13, $229-254$. [CrossRef]

61. Artazcoz, L.; Cortès, I.; Puig-Barrachina, V.; Benavides, F.G.; Escribà-Agüir, V.; Borrell, C. Combining employment and family in Europe: The role of family policies in health. Eur. J. Public Health 2013, 24, 649-655. [CrossRef] [PubMed]

62. Boye, K. Work and mental wellbeing in a comparative perspective-The role of family policy. Eur. Sociol. Rev. 2011, 27, 16-30. [CrossRef]

63. Grönlund, A.; Öun, I. Rethinking work-family conflict: Dual-earner policies, role conflict and role expansion in Western Europe. J. Eur. Soc. Policy 2010, 20, 179-195. [CrossRef]

64. Lyness, K.S.; Judiesch, M.K. Gender egalitarianism and work-life balance for managers: Multisource perspectives in 36 countries. Appl. Psychol. 2014, 636. [CrossRef]

65. Setterlind, S.; Larsson, G. The stress profile: A psychosocial approach to measuring stress. Stress Med. 1995, 11, 85-92. [CrossRef]

66. Nyberg, A.; Westerlund, H.; Magnusson Hanson, L.L.; Theorell, T. Managerial leadership and ischemic heart disease among employees: The Swedish WOLF study. Occup. Environ. Med. 2009, 66, 51-55. [CrossRef]

67. Sundin, L.; Bildt, C.; Lisspers, J.; Hochwälder, J.; Setterlind, S. Organisational factors, individual characteristics and social support: What determines the level of social support? Work 2006, 27, 45-55. [PubMed]

68. Grossi, G.; Theorell, T.; Jurisoo, M.; Setterlind, S. Psychophysiological correlates of organizational change and threat of unemployment among police inspectors. Integr. Physiol. Behav. Sci. Off. J. Pavlov. Soc. 1999, 34, 30-42. [CrossRef] [PubMed]

69. Hallman, T.; Burell, G.; Setterlind, S.; Oden, A.; Lisspers, J. Psychosocial risk factors for coronary heart disease, their importance compared with other risk factors and gender differences in sensitivity. J. Cardiovasc. Risk 2001, 8, 39-49. [CrossRef]

70. Hallman, T.; Perski, A.; Burell, G.; Lisspers, J.; Setterlind, S. Perspectives on differences in perceived external stress: A study of women and men with coronary heart disease. Stress Health 2002, 18, 105-118. [CrossRef]

71. Lisspers, J.; Almén, N.; Sundin, Ö. The Effects of a Recovery-Focused Program for Stress Management in Women-An Exploratory Study. Health 2014, 6, 2825-2836. [CrossRef]

72. Strandh, M.; Hammarström, A.; Nilsson, K.; Nordenmark, M.; Russel, H. Unemployment, gender and mental health: The role of the gender regime. Sociol. Health Illn. 2013, 35, 649-665. [CrossRef] [PubMed]

73. Daoud, J.I. Multicollinearity and Regression Analysis. J. Phys. Conf. Ser. 2017, 949, 012009. [CrossRef]

74. Allvin, M.; Aronsson, G.; Hagström, T.; Johansson, G.; Lundberg, U. Work without Boundaries. Psychological Perspectives on the New Working Life; Wiley-Blackwell: Oxford, UK, 2011. [CrossRef]

75. Joyce, K.; Pabayo, R.; Critchley, J.A.; Bambra, C. Flexible Working Conditions and Their Effects on Employee Health and Mental Wellbeing; Cochrane database of systematic reviews (Online); Cochrane: London, UK, 2010; Volume 2, p. CD008009.

76. Forte. Arbetsmiljö i Kvinnodominerade Sektorer [Working Conditions in the Female Dominated Working Sector]; Forskningsrådet för Arbetsliv och Hälsa [Swedish Research Council for Health, Working Life and Welfare]: Stockholm, Sweden, 2016.

77. Grawitch, M.J.; Gottschalk, M.; Munz, D.C. The path to a healthy workplace: A critical review linking healthy workplace practices, employee mental wellbeing, and organizational improvements. Consult. Psychol. J. 2006, 58, 129-147. [CrossRef]

78. Kelloway, E.K.; Teed, M.; Kelley, E. The psychosocial environment: Towards an agenda for research. Int. J. Workplace Health Manag. 2008, 1, 50-64. [CrossRef]

79. Almén, N.; Lisspers, J.; Öst, L.-G. Stress-Recovery Management: A Pilot Study Using a Single-Subject Experimental Design. Behav. Modif. 2019. [CrossRef] [PubMed] 
80. Bennett, A.A.; Bakker, A.B.; Field, J.G. Recovery from work-related effort: A meta-analysis. J. Organ. Behav. 2018, 39, 262-275. [CrossRef]

81. Sonnentag, S.; Venz, L.; Casper, A. Advances in recovery research: What have we learned? What should be done next? J. Occup. Health Psychol. 2017, 22, 365-380. [CrossRef] [PubMed]

82. Geurts, S.A.E.; Sonnentag, S. Recovery as an explanatory mechanism in the relation between acute stress reactions and chronic health impairment. Scand. J. Work Environ. Health 2006, 32, 482-492. [CrossRef]

83. Almén, N.; Lisspers, J.; Öst, L.-G.; Sundin, Ö. Behavioral stress recovery management intervention for people with high levels of perceived stress: A randomized controlled trial. Int. J. Stress Manag. 2019. [CrossRef]

(C) 2020 by the authors. Licensee MDPI, Basel, Switzerland. This article is an open access article distributed under the terms and conditions of the Creative Commons Attribution (CC BY) license (http://creativecommons.org/licenses/by/4.0/). 